\title{
Biological methods to predict the nutritive value of tropical and mediterranean feedstuffs: a critical review
}

\author{
P Susmel, S Filacorda \\ Dipartimento di Scienze della Produzione Animale, Via S. Mauro 2, 1-33010 Pagnacco (UD), Italia
}

\begin{abstract}
Summary - In Mediterranean and tropical areas, the specific characteristics of the plants and herbivores are the result of co-evolutive mechanisms and the interactions between feed and animal are more important than under temperate conditions. The biological methods available to predict nutritive value have been proposed and developed under temperate conditions and simulate or describe mainly feed utilisation in the rumen. In general, these methods do not produce unique and comparable results, because they are capable of measuring either the whole rumen digestion, or the fermentation process, or the degradation process or microbial synthesis individually. In addition, the biological methods have different levels of simplification of the feed utilisation process and take into account, in different manners, the level of intake, the association between feeds, the recycling of Nitrogen $(\mathrm{N})$ in the rumen and the rate of rumen passage. In order to predict the nutritive value of tropical and Mediterranean feedstuffs, biological methods have been compared in terms of their general and specific approach, level to robustness and sensitivity, specific requirements and level and type of predictability. In addition, the main differences between tropical and temperate forages are described and discussed.
\end{abstract}

\section{Introduction}

In Mediterranean and tropical areas, the specific characteristics of plants and herbivores are the result of co-evolutive mechanisms. The plants in tropical and subtropical areas have developed a series of anatomical and biochemical strategies to adapt to a series of pressure factors: high temperatures, high evaporation, shortage of water and pressure from herbivores.

Domestic animals have developed as a response to limitations in the quality and quantity of the allowance of feeds, specific anatomical and physiological characteristics and have covered a specific ecological and nutritional niche. The various species of domestic animals can be distinguished by their different feeding behaviour and food preference, rumen environment, kinetics of nitrogen recycling and transit time of feeds. At the same time, different management systems represent an adaptation to the ecological conditions and simultaneously represent an evolutionary element in their own right. Under tropical and Mediterranean conditions, the nutritional habits of domestic animals depend on the feeding systems, feed allowances and feeding behaviour and, therefore, during the year and the day, the diet can change widely in type of feed and quality of nutrients.

This series of factors influences the estimation of the nutritional value of tropical feeds.

Biological methods, used to assist the evaluation of the nutritional value of tropical feeds, represent models which simulate a part of the feed utilisation process, with different levels of complexity; the information obtained generally describes and predicts intake, digestibility and the protein value. These methods have been developed for temperate feeds and generally show a lower capability of describing and giving useful information on the nutritional value of tropical and subtropical feeds. There is thus a need to compare and study the different methods in a series of analytical, technical and methodological approaches to identify the critical points.

\section{Structure and chemical composition}

The nutritive value of forage feeds for ruminant production is a function of two dependent factors: voluntary intake and feed utilisation. Plant characteristics affecting voluntary intake are palatability (taste, odour and surface 
characteristics), leaf to stem ratio, plant habit and dimensions of stems and leaves (Stone, 1994). Plant characteristics which affect feed utilisation depend upon both internal (composition and structure) and external (plant anatomy and morphology) plant cell wall factors (Chesson and Forsberg, 1988). Cellular constituents, leaf and stem strength, antinutritional factors and toxins are additional factors affecting feed utilisation. Confined and grazing animals have different feeding behaviour and have distinct possibilities of selection, both between and within feeds; this means that autoregulatory intake processes can be different.

Environmental conditions greatly affect the plant nutritive value. High growth temperatures are an important factor in accelerating plant maturity, but it is possibly that they also lead to changes in plant anatomy. Differences in plant anatomy between tropical and temperate grasses are linked to the different types of photosynthetic pathway, $\mathrm{C}_{4}$ and $\mathrm{C}_{3}$, respectively (Wilson, 1994) and are measured as proportions and spatial arrangements of tissues within organs. These differences are quite large in leaves, while in leaf sheath they are smaller and are not expressed in stems. Temperate grass leaves have more mesophyll than $\mathrm{C}_{4}$ grasses and this tissue appears to more loosely arranged than that of $\mathrm{C}_{4}$ species, allowing easier penetration by microbes (Akin, 1986). Tropical grass leaves have a higher proportion of thick walled tissues, such as vascular bundles and sclerenchyma than temperate pasture grasses (Akin, 1989). Furthermore, in warm season grass leaves, vascular bundles are more closely spaced and have a distinct, thick walled parenchyma bundle sheathes (PBS) surrounding each bundle, whereas cool season grasses have widely spaced bundles and a less distinct PBS (Akin, 1986). In consequence, warm season PBS, which contain more than $50 \%$ of the leaf reserve carbohydrates and protein, are slowly or only partially digested, whereas that of cool season grasses is rapidly and extensively digested. In some genera of $\mathrm{C}_{4}$ grasses, an additional barrier (suberized lamella) often appears within the outer section of the bundle sheath wall, which is completely indigestible, but is not present in $C_{3}$ grasses (Wilson, 1993).

Outer tangential cells of epidermis of both tropical and temperate forages become thickened, lignified and completely covered with epicuticular waxes and cutin, which represent an important physical barrier for penetration of micro-organisms and gas and water exchange. In most cultivated temperate grasses, the epidermis is attached to the body of the leaf through mesophyll cells and thus quickly removed by chewing and rumination. In contrast, in tropical grass leaves and in many wild temperate grass leaves, the epidermis is attached to the leaf at vascular bundles through thick-walled sclerenchyma cells and is not readily lost by chewing and ruminating (Wilson, 1993). Furthermore, the walls of tropical grass epidermal cells in the paradermal view are sinuous in a form linking adjacent cells together with strong "dove-tailed" joints, whereas in most temperate grasses the walls are straight-sided. The straight-sided walls are easily separated along the middle lamella which is not the case with sinuous walls where breakages must occur by splitting across walls and not by separation at the middle lamella.

In legumes there appear to be no group differences in anatomy and cell wall characteristics between tropical and temperate species (Wilson, 1993). Legume leaf digestibilities are mostly high and the species with particularly low values have been largely linked to high tannin levels rather than anatomical problems. Tannins, which are present in warm season dicotyledons in appreciable amounts, can affect both feed intake (palatability because of their astringency) and feed utilisation (form complexes with feed proteins, enzymes and polysaccharides) (Kumar and Singh, 1984; Leinmueller et al, 1991), but there are also reports that small quantities of tannins (3-4\% of DM) show positive effects by preventing excessive rumen degradation of dietary protein and reducing the risk of bloat (Mangan, 1988; Leinmueller et al, 1991).

Decreasing digestibilities of thick-walled plant tissues are in close relation with their degree and the chemical nature of their lignin/phenolic composition (Wilson, 1990). All forages contain lignin, but the concentrations are higher in legumes than grasses (Jung, 1989) and slightly higher in $C_{4}$ than $C_{3}$ grasses (Akin and Chesson, 1989). Furthermore, grass stems contain higher quantities of lignin and phenolic acids than leaves (Lavrencic et al, 1994, unpublished). Warm season grasses are also characterised by the presence of greater amounts of esterified phenolic acids such as p- 
coumaric and ferulic acid. Legumes contain much smaller amounts of phenolic acids than grasses. The total lignin concentration increases in forages with the physiological maturity of stem and leaf tissue. High growth temperatures have a greater influence on increasing lignin concentration in cool season grasses than warm season grasses (Akin and Chesson, 1989). The chemical nature of lignin seems to be another important factor limiting cell wall utilisation (Buxton and Russell, 1988; Reeves, 1985a, 1985b).

In addition, Kerley et al (1988) and Chesson and Forsberg (1988) suggested that the fine structure of cell wall polysaccharides, such as cellulose crystallinity and hemicellulose side-chain substitutions may have an influence on the rate and extent of microbial digestion. Furthermore, some linkages between cell wall constituents such as phenolic ester and/or ether bridges between hemicelluloses and between hemicelluloses and lignin, diisotyrosine bridges between wall proteins and linkages between lignin and wall proteins may limit the access of microbial enzymes to the substrate (Jung, 1989; Jung and Deetz, 1993; Akin and Chesson, 1989).

\section{General aspects of biological determinations}

The biological methods were created to represent and simulate a part or a series of parts of the digestive tract and digestion processes in animals. We have considered the digestibility with in vivo trials; the two stage technique (Tilley and Terry, 1963), one stage technique (Smith et al, 1971; Lindgren, 1979; Shahjahan et al, 1993), the in situ technique (Demarquilly and Chenost, 1969, and Chenost et al, 1970, modellized by Mehrez and Ørskov, 1977; ørskov and McDonald, 1979), in vivo cannulated animals (Hveplund et al,1976; Thomas, 1978), allantoin (Topps and Elliott, 1965; Rys et al, 1975), in vitro continuous culture (Czerkawski and Breckenridge, 1977; Hoover et al, 1976a, 1976b) and in vitro gas production (Menke and Steingass, 1988).

The "basic model" which gives the value utilised for defining the nutritive value of a feed is the in vivo digestibility; this represents the entire process which occurs in the gastrointestinal tract. The other methods simulate the rumen tract and in the case of cannulated animals and the two stage technique, the gastric digestion is integrated with the rumen digestion.

The methods consider and study a series of biological and physical processes which differ considerably between themselves.

The basic value obtained in in vivo trials is the result of the integration of two main processes: digestion and absorption; the other systems consider degradation (in situ), fermentation (gas test) and microbial synthesis (allantoin and cannulated animals) or digestion (two stage and one stage techniques). The consequence of these different approaches is that the information provided is different in type, unit of measurement and its distribution over time. The results can have a unique value or/and be a series of estimated parameters according to the different approach considered; the methods which utilise models for the estimation of parameters as a function of time can be considered to have an explicitly dynamic approach, while the methods which give a single final result, without a time variable, can be considered explicitly static; however, these methods can give unique information which is the result of an implicitly dynamic process.

Digestibility trials, cannulated animals and allantoin give a single data point for the digestibility process which is the result of a balance from several days of measurements of a dynamic process.

The two stage technique, which gives only the end of point of digestion (Tilley and Terry, 1963; Theodorou et al, 1994), is an implicitly static approach.

An evolution of the two stage technique (Smith et al, 1971; Shahjahan et al, 1993), without the second stage and with different times of observations, has been developed to obtain the extensive kinetics of degradation of organic matter and cell wall components and can be considered explicitly dynamic but is still implicitly static. The in situ technique is used to obtain an estimate of the parameters of the kinetics of degradation with a application of a exponential equation (ørskov and McDonald, 1979; McDonald, 1981; Robbinson et al, 1986) or to have a series of observations at precise times (Judkins et al, 1990). The same technique can be used for the continuous culture method in which the sample can be incubated for different times to obtain a kinetic or an absolute value. The last two methods can 
be considered to have an implicitly dynamic approach.

Generally in the one stage, in situ and continuous culture techniques, a single homogeneous feed component is considered to be present and to have a first order digestion kinetic. This approach can be due to the limited number of observations and the easy utilisation and interpretation of the estimated parameters. This represents too simple an approach, especially for feeds which have a high percentage of cell wall, without constant degradation kinetics (Van Milgen et al, 1993).

In vivo methods can also be used to estimate the transit time and bacterial synthesis, obtaining a series of kinetic parameters generally using a non constant rate of passage, and with the utilisation of a multicompartmental and age dependent model (Moore et al, 1992).

The gas test represents a system adapted to yield continuous information (Menke and Steingass, 1988; Pell and Schofield, 1993; Theodorou et al, 1994) and the high numbers of observations enable the application of models with the presence of several feed components and a sigmoidal approach (Beuvink and Kogut, 1993, Schofield et al, 1994).

The methods can be also divided in "open" or "closed" systems; the level of openness represents the possibility of entering and modifying the process over time; generally, in open systems, the input can be introduced at any time, can be modified and the final metabolites can leave the system without interfering with the biological phenomena.

Coupled to this type of division, the systems are divided into types of family: in vivo, in situ and in vitro methods; a partly continuous culture, i.e. the in vitro systems, are closed and the in situ and in vivo methods are open.

The other important distinction is the nature of the wall of the system which can be biological, for the in vivo and in situ methods, or inert for the in vitro methods.

\section{Variables to be considered}

In warm climate zones, the present animals species differ widely in terms of their digestive physiology and anatomy, their philogeny and their relative ecological niche; these differences lead to a series of specific characteristics : a) different feeding behaviour b) a specific rumen environment c) kinetics of recycling of nitrogen d) different transit time. These differences are not only inter-species but are, in some cases, intraspecific, as a function of breed, different area of origin or feeding system. Research has described the differences in digestibility for some tropical feeds across species (El Hag, 1976; Doyle et al, 1984; Domingue et al, 1991; Lechner-Doll et al, 1990; Kayouli et al, 1993) and between breeds (Silanikove, 1986).

The methods have different levels of complexity because of the numbers of variables considered; it is possible to consider four variables and their relative effects: level of intake, associative effects, recycling of nitrogen and transit time. These variable can be present in the system under different forms: as constitutional, implicit components, as integrated components or as absent variable.

The level of intake for in vivo methods is a constitutional part of the system while in vitro methods are unable to consider these aspects. Several researchers consider that the two stage technique is an unreliable estimate of in vivo digestibility because the static approach that does not consider the effects of intake level (Van Soest, 1982); this criticism can be extended to all the "closed" in vitro systems. The transit time, a variable closely associated with the level of intake, is an intrinsic variable in the in vivo methods and in continuous culture techniques it can be simulated and integrated (Czerkawski and Breckenridge, 1977; Hoover et al, 1976a, 1976b). In the in situ, the passage rate is integrated in the model used to estimate the effective degradability (Ørskov and McDonald, 1979); the value of the rate used in the in situ method are constant and have generally been measured for temperate feeds, without any investigations on tropical animal species and diets. In vitro closed systems lack the rate variable and this represents a limit to the dynamic interpretation of the phenomena (Ellis, 1978). Associative effects are considered in the in vivo digestibility methods as an intrinsic aspect, and indeed the allantoin method represents the final result of these phenomena at the rumen level. Fistulated animals are used to detect the associative effects in the reticulorumen (Archimede et al, 1995a), and in the in situ technique these effects can be studied (Flachowsky and Schneider, 1992; Archimede et al, 1995b) but the results do not consider the 
rumination process, passage time of feeds and the phenomenon of compensation of digestion. The in vitro closed techniques are considered inadequate to examine this effect (Mehrez et al, 1983), although there are possibilities of using the continuous culture method for such investigations.

The recycling of nitrogen represents another important factor for understanding the nutritional ecology and the adaptability of species which eat roughages (Watson and Norton, 1982). The open systems take this into account as an intrinsic factor; otherwise, the closed in vitro methods cannot replicate this aspect in dynamic terms and with continuous culture the $\mathrm{NH}_{3} \mathrm{~N}$ represents an unstable fermentation characteristic (Mietinen and Setälä, 1989). In in vivo trials the different behaviour of nitrogen recycling studied between species present in warm countries should be considered.

\section{Factors affecting biological methods}

The systems have different degrees of sensitivity to a series of factors and have critical points in which an apparently small modification in the conditions leads to a large modification of the estimated parameters and the overall result.

The initial conditions have different meaning for the different techniques and should generally represent the optimal conditions for gastrointestinal function (Van Soest, 1982) and normal feeding behaviour (Done-Curry et al, 1984). In the in vivo methods, the initial trial conditions generally have a low weight because the final result is the combination of the adaptation period and the observation period. The other methods can be influenced to variable degrees by the initial conditions - the more evident sensitivity with respect to the in vivo digestibility trials is in dependence for the different length of the period and times of observation, the model applied and the nature of the system; in in situ trials, the estimation of soluble fractions and the degradation kinetics are very sensitive to the initial conditions and to the first observation.

For the in vitro methods, the initial conditions are very important; the precision and variability of the results depend on the composition and activity of the rumen liquid
(Aerts et al, 1977) and in turn these are dependent upon time of collection and type of diet (Judkins et al, 1990).

The basal diet represents a strong source of variability in the in situ and in vitro methods which need a source of rumen inoculum; the concentrate to forage ratio and the level of intake affect the rumen degradability of temperate feedstuffs (Lindberg, 1981; Weakly et al, 1983; Susmel et al, 1989) and tropical feeds (Zhao et al, 1993). In particular, an increase in both these factors causes, for tropical feeds, the degradability to decrease (Zhao et al, 1993). For the in vitro closed methods, the type of diet represents a strong source of modulation of the activity of rumen inoculum (Judkins et al, 1990; Susmel et al, unpublished).

The use of mixed diets in digestibility trials can allow a series of phenomena to confuse the estimate of digestibility of the fibrous feed, by enhancing the activity of the amylolytic microflora through a change in rumen $\mathrm{pH}$ (ørskov, 1983), and/or by a competition between the amylolytic and fibrolytic populations for the substrates rich in non structural carbohydrates (Tamminga, 1993). In these two cases, the fibre digestion kinetic is depressed and modified leading to misleading digestibility value.

The end products represent another source of variability; in the in vitro closed and open systems, they can be a disturbance factor for the estimate, while in open systems the influence is limited. This is due to the impossibility of the in vitro methods to absorb the end products, causing a shift in the microbial population (Mansifield et al, 1995).

Bacterial contamination can have different levels of influence according to the method and feed utilised. For the in vivo methods, i.e. digestibility trials and cannulated animals, the influence is lower than in situ and the one stage and two stage in vitro techniques, if these avoid treatment with Neutral Detergent solution, (Goering and Van Soest, 1970). Bacterial contamination can be represent a strong source of error, especially for poor quality feeds and for estimates of protein degradability in situ (Varvikko, 1986). For the gas test and the allantoin technique, the effect is absent because of the nature of the estimate and the mechanism involved (fermentation and microbial synthesis, respectively).

The presence of antinutritional factors 
(ANFs) have more significance for the closed in vitro systems because they represent a source of selection against the microbial population leading to a depression of cellulose degradation (Muinga et al, 1992). In the nylon bag technique, if a different basal diet to the feed being tested is used, as the latter only represents a very small portion of the total rumen contents, any adverse effects of the slow release of the ANFs on the activity of the rumen microorganisms would be masked (Jones et al, 1992); the other techniques have level of sensitivity intermediate between the in situ and closed in vitro technique.

The methods have different sensitivity to the amount, representativeness and physical form of sample. Generally, the methods that use the mastication and rumination process in the animal are less sensitive to the physical form of the feed. The in vitro systems are highly influenced by the amount and physical form of the sample and the same phenomena influencing the in situ methods; the effect of amount and physical form is the consequence of the ratio between surface area available for degradation and the amount of rumen liquid; in the case of the in situ method, the ratio is dependent upon the volume of the micro habitat in the bag and the pore size which may cause a selection of the microbial population.

For the in situ method, experimental results report a general increase of degradability for more finely milled samples (Susmel et al, 1990) with different behaviour for different feeds (Michalet-Doreau and Ould-Bah, 1992). The methods with a micro habitat have to confront the problem of the need for a small quantity of feed, while the in vivo digestibility needs a comparatively huge of quantity of forage, and this may be difficult to obtain especially in arid area if there is a need for fresh feed.

The importance of the quantity and the physical features of samples is smaller in the methods which have a macro habitat and with a natural turnover rate. The representativeness of a sample is particularly important for the methods in which it represents the only source of feed (e.g. for the microbes), and this is especially the case for tropical feeds in which there are not only differences between leaves and stems, but also between different fractions of the stems (Navaratne et al, 1990); for all systems, for these forages is important to have a representative sample to what the animal has actually consumed.

\section{Level of prediction}

Each system has different prediction objectives: in vivo digestibility trials represent the basic value for digestibility and intake of dry matter; for voluntary intake. The digestibility trials are often conducted with mixed diets because of the impossibility of having a maintenance level; in this case, the estimate of the digestibility of fibre-rich feeds, given in a mixed diet, should not be considered an absolute value but a value relative to the ration in which it is included (Pigden et al, 1980).

For tropical forages, in vitro techniques gives different values of correlation with different types of feed and the coefficients obtained are difficult to compare; the influences of chemical variables (NDF and protein) are also different for the different classes of feeds (Navaratne et al, 1990). However, the level of prediction is always lower than temperate feeds and is often not significant. The continuous culture technique gives a result similar to in vivo values but these systems use low DM inputs and liquid dilution rates which are less than in vivo estimates (Mansifield et al, 1995).

The degradability of dry matter and NDF seems to be the most important variable for describing the nutritive value of some tropical feeds (Vadiveloo and Fadel, 1992) although for feeds rich in tannins the in situ values do not represent a good description of the true nutritive value (Makkar et al, 1989; Vadiveloo and Fadel, 1992; Jones et al, 1992).

The cannulated animals method represents a good technique for estimating digestibility, especially for feeds rich in structural carbohydrates (Archimede et al, 1995b) but this technique is less accurate than those involving the whole tract (classical digestibility trial).

The allantoin method does not give any indications about digestibility, an estimate of bacterial synthesis. The gas production method and its associated mathematical models can be used to give a prediction of energy and organic matter fermentation of tropical feeds (Krishnamoorthy et al, 1995) and detect the presence of different components in the feed (Beuvink and Kogut, 1993), the effective kinetics of degradation (France et al, 1993) and to identify the different stoichiometric coefficients for different feed components from the gas production (Pell and Schofield, 1993; 
Filacorda and Stefanon, 1995); this method generally has a higher prediction level for hays than two stage technique, but is slightly worse than in situ (Khazaal et al, 1993a).

For dry matter intake, the levels of predictability are good with the parameters obtained in situ (ørskov et al, 1988; Reid et al, 1988 ) and from the gas test (Blümmel and Orskov, 1993; Khazaal et al, 1993a) while the one and two stage techniques have a low correlation with the observed intake for hay (Khazaal et al, 1993a) shrubs and Mediterranean feeds (Susmel et al, 1993a). The continuous culture, allantoin and cannulated animal techniques are generally not used for estimating intake.

The protein value of a feed is estimated with a specific prediction system; the value obtained from in vivo digestibility trials can only represent a source of information for the energy allowance for the bacterial growth but gives no information on the protein allowance. The in situ (INRA, 1988; Sniffen et al, 1992; Susmel et al, 1993b) cannulated animal (Rohr et al, 1986) and allantoin methods (Topps and Elliott, 1966; Rys et al, 1975) give information which is utilised for the estimate of a protein value. For the cannulated animals, the estimation of microbial protein yield is achieved using microbial markers, substances which are capable of identifying the microbial cells and which have a constant ratio with the DM or nitrogen; of the markers available, the most frequently used are ATP, RNA, DAPA and isotopes ( $\left.{ }^{15 N},{ }^{35} \mathrm{~S}\right)$ (Demeyer and Tamminga, 1987; Satter et al, 1986; Susmel et al, 1993c). If the allantoin method is used to obtain an estimate of microbial production, there is a need to consider a series of coefficients which appear to be species dependent (Liang et al, 1994) and this aspect needs of more investigation. The data obtained also requires correcting for the endogenous contribution and represents a static value without information on digestion kinetics. The results obtained with the continuous culture (Rusitec), have been shown not to reproduce the rumen or in vivo degradation patterns of carbohydrates and protein (Czerkawski and Breckenridge, 1985; Jayasuriya et al, 1987; Susmel et al, 1991; C.R. Mills, personal communication) and give different estimates for the protein value with respect to the value obtained in vivo (Mansifield et al, 1995). The one and two stage techniques are not adapted for roughages and are not sufficient alone, for supplements, to give good information on protein values (Sehgal and Makkar, 1994). In any case, some authors (Antongiovanni et al, 1993; Stefanon and Guzzon, 1995) have attempted to use the dry matter disappearance, at the end of digestion to determine the amino acid profile of the feed and the entire contents of the Tilley and Terry digestion tube. The gas test is not currently used to describe the protein value but could, in the future, be a potential source of information of bacterial activity and growth (Pell and Schofield, 1993).

In the case of feeds treated or/and supplemented with nitrogen, in vivo trials give the reference information; several authors (Kartchner and Campbell, 1979; Holechek et al, 1986) have reported inaccuracies in the closed in vitro technique for estimating digestibility of $\mathrm{N}$-supplemented diets, so inaccuracies can be detected in situ if different basal diets are used (Makkar and Singh, 1993). The continuous culture (Owen et al, 1991), allantoin and cannulated animal techniques can be used to study these effects.

In addition to the variables described above, the methods can detect the presence of certain compounds, especially volatile fatty acids (VFA), tannins and phenols and secondary metabolites.

VFA are routinely detected with the continuous culture (Czerkawski and Breckenridge, 1977; Hoover et al, 1976a, $1976 \mathrm{~b}$ ) and can be studied in the one stage, gas test (Blümmel and ørskov, 1993) and fistulated animal techniques.

The presence and the effect of tannins and phenols can be verified with in vitro closed methods; these methods (gas test) can detect, with the addition of Polyvinylpyrolidone (Khazaal et al, 1994) the presence of antinutritional compounds but this aspect requires further investigation; in the one stage technique, the kinetics of phenolic compound digestion can be studied (Shahjahan et al, 1993). For the in vivo and continuous culture techniques, it is possible to study these compounds, while for the in situ method they are difficult to detect (Khazaal et al, 1993b; Khazaal et al, 1994). The secondary metabolites with an activity on the neural metabolism of the host can be studied with the in vivo trials and can only be detected with the in vivo technique.

The predictability of transit time is 
associated with the use of exogenous markers utilised with fistulated animals and the in situ technique. The flow of solid and liquid phases from the rumen is estimated with markers of the particulate phase, such as chromium or the rare earth elements ( $\mathrm{Yb}, \mathrm{Ce}, \mathrm{La}$,) mordanted to the fibre, while the liquid phase is often marked with polyethyleneglycol, cobalt or chromium in EDTA complexes (Demeyer and Tamminga, 1987; Rohr et al, 1986; Satter et al, 1986). These markers are also used in the in vivo digestibility to define the flow of solid and liquid along the gastro-intestinal tract and in the rumen, to detect the different kinetics of feed and between the animals species present in tropical areas (Lechner-Doll et al, 1990; Kayouli et al, 1993).

\section{Specific requirements of the methods and recommendations}

The methods have different experimental housing requirements and have different degrees of utilisation of animal. In vivo digestibility trials need not less than three entire animals to have a good repeatability of the results (Heaney, 1979): the time required is about three weeks to one month of adaptation and one week of measurements and the amount of feed needed is large. With an experimental design defined to cover the effect of time, the other in vivo methods need different amounts of feed. In in vivo and in situ trials, the level of intake should represent the maintenance level; this condition for poor or unpalatable feeds is difficult to obtain, although, at the same time, this probably does not represent the true feeding conditions in the tropics. Under these experimental conditions, it is important to use a type and percentage of supplement which does not give an abrupt alteration of the "normal» rumen environment, but which enhances the optimal digestion of dry matter and structural carbohydrates.

The use of cannulated animals should consider the higher RSD and the need of a sufficient number of animals (Archimede et al, 1995a). For this method, from a practical point of view, there are considerable difficulties and, for some aspects, criticisms, especially concerning the accuracy of the evaluation obtained with microbial markers and flow of the rumen phases. Considerable variations of microbial flow are often reported to be due to the type of marker, the sampling site and analytical procedures (Demeyer and Tamminga, 1987; Satter et al, 1986).

The closed in vitro methods require the presence of 2 animal donors and the trials can be conducted from 48 to 96 hours with 3 replications and two sequential weeks of analysis; only small quantities of feed are needed, together with forage standards, with known digestibility, to allow the control of variation in the conditions. The rumen liquid can be substituted with a pure culture obtained in vitro or with the Rusitec liquid effluent (Owen et al, 1991); the values obtained, even for subtropical roughages, are comparable to values measured with rumen liquid with a slightly negative systematic difference.

Most discussion is related to the time of incubation (Holechek et al, 1986) and level of supplementation of $\mathrm{N}$ in the inoculum; however, timing and amount of supplement have not been well established (Galyean et al, 1987) and depend on forage, diet quality and botanical composition, as well as accuracy of working. There is the need to preserve anaerobiosis and to have a sufficient concentration of nitrogen in the medium to maintain the activity of the bacterial population; this is particularly the case for feeds with a low percentage of nitrogen.

Gas production does not have a constant proportional coefficient with the degraded substrate, especially in the first few hours of fermentation and after the 36th hour of fermentation. This could be due to the growth and adaptation of the bacteria in the first hour of fermentation and the accumulation of toxic residues in the later period (Filacorda and Stefanon, 1995); for this reason, the kinetic parameters should be utilised with caution.

The in vitro systems, used routinely, should not require a large input of electricity but there is a need for an uninterrupted supply (Owen et al, 1991).

The in situ method needs not less than three fistulated animals and 10 days of adaptation and 140 hours of incubation; for feeds with slow degradability, it should be considered that a change of one point of transit rate can considerably affect the results, as observed by Kamatali et al (1992) and particular attention should be given to the use and estimation of the lag phase (Kaitho et al, 1993; Kamatali et al, 1992) and the use of soluble fractions (France et al, 1993; Dewhurst et al, 1995). 
For the continuous culture technique, fresh sheep faeces can be used as a source of micro-organisms for commencing the Rusitec (El Shaer et al, 1987) and the time needed is from 7 to 15 days.

Generally, in the systems without mastication by the animals, the definition of the dimension of milling, for different animal species, should be accounted for by different systems of mastication and specific particulate sizes present in the rumen.

More attention should be given to the use of the estimated parameters and care should be exercised in applying predicting equations for the nutritive value of feeds: some authors (Navaratne et al, 1990; Shem et al, 1995; Khazaal et al, 1993a) utilise the parameters principally on the basis of their statistical relevance (maximising the coefficient of determination) rather than any biological meaning. The consequence is that single or multiple regressions obtained can be difficult to understand and compare from a biological and nutritional point of view.

\section{Conclusions}

The different biological methods try to represent and simulate only one or a few sites and mechanisms of feed utilisation, with different levels of complexity. The information obtained from them is often impossible to compare and is often used not for the biological meaning but simply for a statistical contribution to regressions with data obtained from in vivo trials.

These methods do not give general and reliable predictions of the nutritive value of feeds from tropical and sub-tropical areas because of a series of factors: lack of systematic investigation, incapability of reproducing or considering the interaction between animal and plant, a static approach and/or unstable behaviour in response to specific characteristics of feeds. The biological methods can and should be used in combination with investigations on possible strategies for feed utilisation. The methods should be integrated to obtain more complete information. The feed should be studied and assembled for its structural characteristics before being tested with any given method.

\section{Literature cited}

Aerts JV, de Branbader DL, Cottyn BG, Buyesse FX (1977) Comparison of laboratory methods for predicting the organic matter digestibility of forages. Anim Feed Sci Technol 2, 237-249

Akin DE (1986) Interaction of ruminal bacteria and fungi with southern forages. J Anim Sci 63, 962977

Akin DE (1989) Histological and physical factors affecting digestibility of forages. Agron $J$ 81, 1725

Akin DE, Chesson A (1989) Lignification as the major factor limiting forage feeding value especially in warm conditions. In: XVI Inter Grass/ Cong, Nice, France, 1753-1760

Antongiovanni M, Stefanon B, Susmel P (1993) Estimation of nutritive value of protein for ruminants with a simple laboratory technique. Atti Seminario ASPA-RAISA Roma, Italia, 127-133

Archimede H, Sauvant D, Hervieu J, Poncet C, Dorléans D (1995a) Digestive interactions in the ruminants: relationships between whole tract and stomach evaluation. Anim Feed Sci Technol 54, 327-340

Archimede $H$, Sauvant $D$, Dorléans $D$, Chapoutot $P$, Poncet $C$ (1995b) Influence of the nature of forage and concentrate on the digestive interactions measured in sacco and in vivo. Anim Feed Sci Technol 54, 341-356

Beuvink JMW, Kogut J (1993) Modelling gas production kinetics of grass silages incubated with buffered ruminal fluid. J Anim Sci 71, 10411046

Blümmel M, Ørskov ER (1993) Comparison of in vitro gas production and nylon bag degradability of roughages in predicting feed intake in cattle. Anim Feed Sci Technol 40, 109-119

Buxton DR, Russell JR (1988) Lignin constituents and cell wall degradability of grass and legume stems. Crop Sci 28, 553-558

Chenost M, Grenet E, Demarquilly C, Jarrige R (1970) The use of nylon bag technique for the study of forage digestion in rumen and for predicting food value. Proc $X I$ Intern Grassl Cong, 7,697-701

Chesson A, Forsberg GW (1988) Polysaccharide degradation by rumen microorganisms. In: The rumen microbial ecosystem (Hobson PN ed) 251 284. Elsevier, London, New York

Czerkawski JW, Breckenridge G (1977) Design and development of a long-term rumen simulation technique (Rusitec). Br J Nutr 38, 371-384

Czerkawski JW, Breckenridge G (1985) Metabolism of protein supplements studied by the rumen 
simulation technique (Rusitec). Arch Tierernähr Berlin 20, 261-278

Demarquilly C, Chenost M (1969) Etude de la digestion des fourrages dans le rumen par la méthode des sachets de nylon. Liaison avec la valeur alimentaire. Ann Zootech 18, 4, 419-436

Demeyer DI, Tamminga $S$ (1987) Microbial Protein yield and its prediction. In: Feed evaluation and protein requirement systems for ruminants. (R Jarrige, G Alderman, eds) Seminar EEC, Brussels, CEC, 129-141

Dewhurst RJ, Hepper D, Webster AJF (1995) Comparison of in sacco and in vitro techniques for estimating the rate and extent of rumen fermentation of a range of dietary ingredients. Anim Feed Sci Technol 51, 211-229

Domingue BMF, Dellow DW, Barry TN (1991) Voluntary intake and rumen digestion of a low quality roughages by goats and sheep. $J$ Agric Sci 117, 111-120

Done-Curry RJ, Hecker JF, Wodziska-Tomaszewska M (1984) Behaviour of sheep transferred from pasture to an animal house. Appl Anim Behav Sci 12, 121-130

Doyle PT, Egan JK, Thalen AJ (1984) Intake digestion and sulfur retention in angora goats and merino sheep fed herbage diets. Austr $J$ Agric Anim Husb 24, 165-169

El Shaer HM, Omed HM, Chamberlain AG, Axford DFE (1987) Use of faecal organism from sheep for the in vitro determination of digestibility. $J$ Agric Sci 109, 257-259

El-Hag GA (1976) A comparative study between desert goat and sheep efficiency of feed utilisation. World Review of Anim Prod 13, 43-48

Ellis WD (1978) Determinants of grazed forage intake and digestibility. J Dairy Sci 61, 1828-1840

Filacorda S, Stefanon B (1995) Description of forage fermentation characteristics with the gas test technique. Atti XI Congresso Nazionale ASPA, 223-224

Flachowsky G, Schneider M (1992) Influence of various straw-to-concentrate ratios on in sacco dry matter degradability, feed intake and apparent digestibility in ruminants. Anim Feed Sci Technol 38, 199-217

France J, Dhanoa MS, Theodorou MK, Lister SJ, Davies DR, Isac D (1993) A model to interpret gas accumulation profiles associated with in vitro degradation of ruminant feeds. $J$ Theor Biol 163 , 99-111

Galyean ML, Krysl LJ, Estell RE (1987) Marker-based approaches for estimation of faecal output and digestibility. In: Feed intake by Beef Cattle: Symp (Owens FN, ed) MP-121, Oklahoma Agric Exp Sta, 121-131

Goering HK, Van Soest PJ (1970) Forage fiber analyses (Apparatus, reagents, procedure and some applications). Agric Handbook, ARS, USDA, Washington, DC, 379

Heaney DP (1979) Sheep as pilot animal in Standardisation of analytical methodology for feeds (Pigden WJ, Balch CC and Graham M, eds) IDRC-134e,44-48

Holechek JL, Wofford $H$, Arthun D, Galyean $M L$, Wallace JD (1986) Evaluation of total faecal collection for measuring forage intake. I Range Manage 39, 2-4

Hoover WH, Crocker BA, Sniffen CJ (1976a) Effects of differential solid-liquid removal rates on protozoa numbers in continuous cultures of rumen contents. J Anim Sci 43, 528-534

Hoover WH, Knowlton PH, Stern MD, Sniffen CJ (1976b) Effects of differential solid-liquid removal rates on fermentation parameters in continuous cultures of rumen contents. J Anim Sci 43, 535542

Hveplund T, Moller PD, Madsen J, Hesselholt M (1976) Flow of digesta through the gastrointestinal tract in the bovine with special reference to nitrogen. In: Year-book, Royal Vet Agr Univ, Copenhagen, 173-192

INRA (1988) Alimentation des bovins, ovins et caprins. INRA Publ, Paris

Jayasuriya MCN, Hamilton R, Rogovic G (1987) The use of an artificial rumen to assess low quality fibrous feeds. Biol Wastes 20, 241-250

Jones RJ, Lefeuvre RP, Palyne MJ (1992) Losses of dry matter, nitrogen, minerals and fibre fraction from nylon bags containing Leucaena leucocephala and two Calliandra species in the rumen. Anim Feed Sci Technol 37, 297-307

Judkins MB, Krysl LJ, Barton RK (1990) Estimating diet digestibility: a comparison of 11 techniques across six different diets to rams. J Anim Sci 68 , 1405-1415

Jung $H G$ (1989) Forage lignins and their effects on fiber digestibility. Agron J 81, 33-38

Jung HG, Deetz (1993) Cell wall lignification and degradability. In: Forage cell wall structure and digestibility (Jung HG, Buxton DR, Hatfield RD, Ralph J, eds) American Society of Agronomy, Madison, 315-346

Kaitho RJ, Tamminga S, Van Bruchem J (1993) Rumen degradation and in vivo digestibility of dried Calliandra calothyrsus leaves. Anim Feed Sci Technol 43, 19-30

Kamatali $P$, Teller E, Vanbelle M, Collignon G, Foulon $M$ (1992) In situ degradability of organic matter, crude protein and cell wall of various tree forages. Anim Prod 55, 29-34

Kartchner RJ, Campbell CM (1979) Intake and digestibility of range forage consumed by livestock. Montana Agric Exp Sta Bull 718 
Kayouli C, Jouany JP, Demeyer DI, Ali-Ali Taoueb $\mathrm{H}_{\text {, }}$ Dardillat C (1993) Comparative studies on the degradation and mean retention time of solid and liquid phases in forestomachs of dromedaries and sheep fed on low-quality roughages from Tunisia. Anirn Feed Sci Technol 40, 343-355

Kerley MS, Fahey GC, Gould JM, lannotti EL (1988) Effects of lignification, cellulose crystallinity and enzyme accessible space on the digestibility of plant cell wall carbohydrates by the ruminant. Food Microstructure 7, 59-65

Khaazal K, Boza J, Orskov ER (1994) Assessment of phenolics-related antinutritive effects in Mediterranean browse: a comparison between the use of the in vitro gas production technique with or without insoluble polyvinylpyrrolidone or nylon bag. Anim Feed Sci Technol 49, 133-149

Khaazal K, Dentinho MT, Ribeiro R, Ørskov ER (1993a) A comparison of gas production during incubation with rumen contents in vitro and nylon bag degradability as predictors of the apparent digestibility in vivo and voluntary intake of hays. Anim Prod 57, 105-112

Khaazal K, Markontonatos X, Nastis A, Orskov ER (1993b) Change with maturity in fibre composition and levels of extractable polyphenols in Greek browse: effects on in vitro gas production and in sacco dry matter degradation. J Sci Food Agric 63 (2), 237-244

Krishnamoorthy $\mathrm{U}$, Soller $\mathrm{H}$, Steingass $\mathrm{H}$, Menke $\mathrm{KH}$ (1995) Energy and protein evaluation of tropical feedstuffs for whole tract and ruminal digestion by chemical analyses and rumen inoculum studies in vitro. Anim Feed Sci Technol 52, 177. 188

Kumar $\mathrm{R}$, Singh $\mathrm{M}$ (1984) Tannins: their adverse role in ruminant nutrition. J Agric Food Chem $32,447$. 453

Lechner-Doll M, Rutagwenda T, Schwartz HJ, Shultka W. Engelhardt WV (1990) Seasonal changes of ingesta mean retention time and forestomach fluid volume in indigenous camel, cattle, sheep and goats grazing a thornbush savannah pasture in Kenya. J Agric Sci 115, 409-420

Leinmueller E, Steingass $H$, Menke KH (1991) Tannins in ruminant feedstuffs. Anim Res and Dev 33, 9-62

Liang JB, Matsumoto M, Young BA (1994) Purine derivative excretion and ruminal microbial yield in Malaysian cattle and swamp buffalo. Anim Feed Sci Technol 47, 189-199

Lindberg JE (1981) The effect of basal diet on the ruminal degradation of dry matter, nitrogenous compounds and cell wall in nylon bags. Swed $J$ Agric Res 11, 159-167

Lindgren $E$ (1979) The nutritional value of roughages determined in vitro and by laboratory method. In: Rep 45, Department of Animal Nutrition, Swedish University of Agricultural Sciences, Uppsala, 1-61
Makkar HPS, Singh B, Negi SS (1989) Relationship of rumen degradability with microbial colonization cell wall constituents and tannin levels in some tree leaves. Anim Prod 49, 299-303

Makkar HPS, Singh B (1993) Effect of storage and urea addition on detannification and in sacco dry matter digestibility of mature oak (Quercus incana) leaves. Anim Feed Sci Technol 41, 247259

Mangan JL (1988) Nutritional effects of tannins in animal feeds. Nutr Res Rev 1, 209-231

Mansifield HR, Edres MI, Stern MD (1995) Comparison of microbial fermentation in the rumen of dairy cows and dual flow continuous culture. Anim Feed Sci Technol 55, 57-66

McDonald ID (1981) A revisted model for estimating of protein degradability in the rumen. $J$ Agric SCi 96, 691-693

Mehrez AZ, Ørskov ER (1977) A study of the artificial fibre bag technique for determining the digestibility of feed in the rumen. J Agric Sci 88 645-650

Mehrez AZ, El-Schinnawy MM, El-Ashry MA, Ead HME (1983) Assessment of the associative effect of roughages and concentrates. J Anim Sci 57 (Suppl 1), 452-453

Menke KH, Steingass $H$ (1988) Estimation of the energetic feed value obtained from chemical analysis and in vitro gas production using rumen fluid. Anim Res Dev 28, 209-221

Michalet-Doreau B, Ould-Bah MY (1992) In vitro and in sacco methods for the estimation of dietary nitrogen degradability in the rumen: a review. Anim Feed Sci Technol 40, 57-86

Mietinen H, Setälä J (1989) Design and development of a continuous culture system for studying rumen fermentation. J Agric Sci Finland 61, 475488

Moore JA, Pond KR, Poore MP, Goodwin TG (1992) Influence of Model and Marker on digesta kinetic estimates for sheep. J Anim Sci 70, 3528-3540

Muinga RW, Thorpe W, Topps JH (1992) Voluntary food intake, live weight change and lactation performance of crossbred dairy cows given ad libitum Pennisetum purpureum (Napier grass var. Bana) supplemented with Leucaena forage in the lowland semi-humid tropics. Anim Prod 55, 331337

Navaratne HVRG, Ibrahim MNM, Shiere JB (1990) Comparison of four techniques for predicting digestibility of tropical feeds. Anim Feed $\mathrm{Scl}$ Technol 29, 209-221

Ørskov ER, McDonald IW (1979) The estimation of protein degradability in the rumen from measurements weighted according to rate of passage. J Agric Sci 88, 645-650

Orskov ER (1983) Supplementation of low quality 
roughages diet for optimal microbial and host animal nutrition. In: Utilisation of low quality roughages with special reference to developing countries Proc workshop on applied research Alexandria (Egypt), 84-87

Ørskov ER, Reid GW, Kay M (1988) Prediction of intake by cattle from degradation characteristics of roughages. Anim Prod 46, 29-34

Owen E, Jayasurya MCN, Hamilton R, Lalenta M (1991) Use of a long-term rumen simulation technique (Rusitec) to provide micro-organism for in vitro digestibility assays. J Agric Sci 116, 297301

Pell AN, Schofield P (1993) Computerized monitoring of gas production to measure forage digestion in vitro. J Dairy Sci 76, 1063-1073

Pigden WJ, Baich CC, Graham M (1980) Standardisation of analytical methodology for feeds; Summary and recommendations. IDRC, $134 \mathrm{e}, 7-14$

Reeves JB (1985a) Lignin composition of chemically treated feeds as determined by nitrobenzene oxidation and its relationship to digestibility. $J$ Dairy Sci 68, 1976-1983

Reeves JB (1985b) Lignin composition and in vitro digestibility of feeds. J Anim Sci 60, 316-322

Reid GW, Ørskov ER, Kay M (1988) A note on the effect of variety, type of straw and ammonia treatment on growth rate of steers. Anim Prod 46, 29-34

Robbinson PH, Fadel JG, Tamminga S (1986) Evaluation of mathematical models to describe neutral detergent residues in terms of its susceptibility to degradation in the rumen. Anim Feed Sci Technol 15, 249-271

Rohr K, Lebzien P, Schafft H, Schultz E (1986) Prediction of duodenal flow of non-ammonia nitrogen and amino acid nitrogen in dairy cows. Livest Prod Sci 14, 29-40

Rys R, Antoniewicz A, Maciejewicz J (1975) Allantoin in urine as an index of microbial protein in the rumen. In: Tracer Studies on Non-protein Nitrogen for Ruminants, II, Intern Atomic Energy Agency, Vienna, 95-98

Satter LD, Combs DK, Lopez-Guisa JM, Nelson WF (1986) Use of markers for measurement of feed digestibility in ruminants. In: Nuclear and Related Techniques in Animal Production and Health Proc Symp, Vienna, Austria

Schofield P, Pitt RE, Pell AN (1994) Kinetics of fiber digestion from in vitro gas production. $J$ Anim $\mathrm{SCl}$ $72,2980-2991$

Seghal JP, Makkar GS (1994) Protein evaluation in ruminants in vitro, in sacco, in vivo protein degradability and microbial efficiency of different protein supplements in growing buffalo calves. Anim Feed Sci Technol 45, 149-165
Shahjahan M, Mosihuzzamam M, Mian AJ (1993) In vitro digestibility studies of some local and high yielding varieties of rice straw (Oryza sativa). Anim Feed Sci Technol 42, 121-130

Shem MN, Ørskov ER, Kimambo AE (1995) Prediction of voluntary dry-matter intake, digestible dry-matter intake and growth rate of cattle from the degradation characteristics of tropical foods. Anim Sci 60, 65-74

Silanikove N (1986) Interrelationships between feed quality, digestibility, feed consumption, and energy requirements in desert (Beduin) and temperate (Saanen) goats. J Dairy Sci 69, 2157 2162

Smith LW, Goering HK, Waldo DR, Gordon $\mathrm{CH}$ (1971) In vitro digestion rate of forage cell wall components. J Dairy Sci 54, 71-76

Sniffen CJ, O'Connor JD, Van Soest PJ, Fox DG Russel JB (1992) A net carbohydrate and protein system for evaluating cattle diets: II Carbohydrate and protein availability. J Anim Sci $70,3562-3577$

Stefanon B, Guzzon P (1995) Effect of substrate on synthesis and quality of microbial protein in vitro. Atti XI Congresso Nazionale ASPA, 223-224

Stone BA (1994) Prospects for improving the nutritive value of temperate perennial pasture grasses. $N$ $Z$ J Agric Res 37, 349-363

Susmel P, Stefanon B, Piasentier E (1989) Effect of forage and concentrate intake level on rumen degradability of protein sources having different in vitro rates of $\mathrm{N}$ solubilisation. Anim Feed $\mathrm{Sci}$ Technol 26, 231-249

Susmel P, Stefanon B, Mills CR, Piasentier E (1990) Impiego di modelli matematici diversi ed effetto della macinazione e della setacciatura sulla degradabilit_ in situ della sostanza secca e dell'N. Zoot Nutr Anim 16, 157-166

Susmel P, Stefanon B, Mills CR (1991) General problems in assessing the nutritive value of Mediterranean forages. In: Fourrages et sous produits méditerranéens (JL Tisserand, G Alibes, eds) Opt Méditer Série A, 16, 17-23, CIHEAM, Saragoza

Susmel P, Mills CR, Spanghero M, Stefanon B (1993a) The prediction of nutritive value and degradability of mediterranean forages by in vitro gas production. Seminario ASPA-RAISA, Roma, Italia, 135-142

Susmel P, Spanghero M, Mills CR, Stefanon B (1993b) A comparison of the French system and the Italian revised proposal for ruminant feed protein evaluation. Atti Seminario ASPA-RAISA Roma, Italia, 105-112

Susmel P, Plazzotta E, Mills CR, Stefanon B (1993C) Determination of RNA and ATP in the rumen liquid of cows fed with diets differing in forage to concentrate ratio. J Sci Food Agric 63, 39-45 
Tamminga S (1993) Influence of feeding management on ruminant fiber digestibility. In: Forage cell wall structure and digestibility 571-602, ASA-CSSASSSA, Madison, USA, 571-602

Theodorou MK, Williams AB, Dhanoa MS, McCallan $A B$, France J (1994) A simple gas production method using a pressure transducer to determine the fermentation kinetics of ruminant feeds. Anim Feed Sci Technol 48, 185-197

Thomas PC (1978) Measurement of the flow of digesta in the post-ruminal gut. In: Ruminant digestion and Feed evaluation (Osbourn DF, Beever DE, Thomson DJ, eds) Agr Res Council, London, England, 3.1-3.10

Tilley JMA, Terry RA (1963) A two stage technique for in vitro digestion of forage crops. $\mathrm{J}$ Br Grass/ SoC $18,104-111$

Topps JH, Elliott RC (1965) Relationship between concentration of ruminal nucleic acids and excretion of purine derivatives by sheep. Nature 205, 498-499

Vadiveloo J, Fadel JG (1992) Compositional analyses and rumen degradability of selected tropical feeds. Anim Feed Sci Technol 37, 265-279

Van Milgen J, Berger LL, Murphy NR (1993) Digestion kinetics of alfalfa and wheat straw assuming heterogeneity of the potentially digestible fraction. J Anim Sci 71, 1917-1923

Van Soest PJ (1982) Nutritional ecology of the ruminant. O\&B Books, Corvallis, OR, $374 \mathrm{p}$

Varvikko T (1986) Microbially corrected amino acid composition of rumen-undegraded protein and amino acid degradability in the rumen of feeds enclosed in nylon bags. Br J Nutr 56, 131-140

Watson C, Norton BW (1982) The utilisation of pangola grass hay by sheep and Angora Goats. Proc Austr Soc Animal Prod 14, 467-470

Weakly DC, Stern MD, Satter LD (1983) Factors affecting disappearance of feedstuffs from bags suspended in the rumen. J Anim Sci 56, 493-498

Wilson JR (1990) Influence of plant anatomy on digestion and fibre breakdown. In: Microbial and plant opportunities to improve lignocellulose utilisation by ruminants (Akin D, Ljungdahl LG, Wilson JR, Harris PJ, eds) Elsevier, New York, 99-117

Wilson JR (1993) Organisation of forage plant tissues. in Forage cell wall structure and digestibility. (Jung HD, Buxton DR, Hatfield RD, Ralph J, eds) American Society of Agronomy, Madison, 1-32

Wilson JR (1994) Cell wall characteristics in relation to forage digestion by ruminants. J Agric Sci 122 , 173-182

Zhao JY, Shimojo M, Goto I (1993) The effects of feeding level and roughages/concentrate ratio on the measurement of protein degradability of two tropical forages in the rumen of goats using nylon bag technique. Anim Feed Sci Technol 41, 261-269 